\title{
The Influence of Posture and Balance on Voice: A Review
}

\section{A Influência da Postura e do Equilíbrio na Voz: Revisão}

Maria Caçador ${ }^{1,2}$, João Paço1,2

\section{ABSTRACT}

The role of posture in vocal performance is recognized for many years. Speech therapists and singing teachers use this knowledge to correct bad postures to improve vocal quality with good results, although most of that knowledge is empirical.

This review evaluates the influence of posture and balance on voice.

Modification in posture secondary to exogenous stimulation can affect voice, while alterations to the voice production mechanism can cause modifications in posture.

Vocal effort results in segmental alterations of posture, accompanied by global postural changes. Dysphonic individuals demonstrate a greater displacement of the centre of gravity forward, which results in postural instability, increasing muscular work to maintain the posture and balance. After vocal rehabilitation, dysphonic patients presented an improvement in posture parameters in static and dynamic posturography.

Posturography evaluation of patients before and after vocal treatment may represent a clinically useful variable in evaluating the efficacy of vocal therapy.

KEYWORDS: Postural Balance; Posture; Voice Quality; Voice Training 


\section{RESUMO}

A importância da postura na performance vocal é reconhecida pela comunidade científica há vários anos. Terapeutas da fala e professores de canto utilizam esse conhecimento empírico para corrigir posturas e melhorar a qualidade vocal dos seus pacientes.

Este trabalho tem o objetivo de fazer uma revisão da literatura sobre a influência da postura na produção vocal.

Modificações da postura por ação de estímulos externos afetam a produção vocal e alterações da produção vocal alteram a postura.

O esforço vocal causa alterações segmentares e globais da postura. Doentes disfónicos apresentam um desvio do centro de gravidade maior do que indivíduos normais, com consequente instabilidade e aumento do trabalho muscular para manutenção do equilíbrio.

Doentes com disfonia apresentam uma melhoria dos parâmetros posturais na posturografia após terapia da fala.

A realização de posturografia, antes e após tratamento com terapia da fala, pode representar um método válido de avaliação da eficácia do tratamento.

PALAVRAS-CHAVE: Equilíbrio Postural; Postura; Qualidade da Voz; Treino da Voz

\section{INTRODUCTION}

The importance of body posture for good vocal performance is well accepted in the scientific literature. ${ }^{1-5}$ Feldenkrais published the first description of the relationship between posture and vocal production in 1949. ${ }^{\circ}$

Vibration of vocal fold mucosa generated by the passage of exhaled air produces a fundamental tone, which, modified by amplification and resonance in the upper airways, results in human voice. Thus, for vocal production, in addition to the correct closure and vibration of vocal folds, dependent on the position of the larynx, good respiratory and resonance function is necessary, functions also profoundly influenced by body posture. ${ }^{1,2}$

The larynx, primarily instrument of human vocal production, is located in the anterior region of the neck, suspended between the skull and trachea by muscles and ligaments, making it particularly vulnerable to changes in position. ${ }^{7}$ The position of the larynx is directly dependent on the movement of the hyoid bone and indirectly reliant on the movements of the head, mandible, temporomandibular joint, cervical spine and scapular girdle. ${ }^{8}$ Several studies have shown that the position of the larynx is important for good vocal quality, any change in position may influence vocal performance, particularly while singing. 9.10 The vertical position of the larynx is directly related to vocal pitch, ${ }^{9}$ vocal loudness and pulmonary volume ${ }^{11}$ and a high larynx position is typically associated with phonatory stress.9.10
The thoracic and abdominal muscles have a role in both breathing and vocal production. Posture plays an essential role in breathing and in the production of lung volume needed to initiate phonation. ${ }^{12}$ In assessing the relationship of posture, breathing, and phonation, the position of the pelvis, should be considered. Several studies $^{13-17}$ have shown the relationship between the activity of the pelvic muscles and the expiratory muscles. The pelvic girdle, therefore, has both a respiratory and postural function. ${ }^{13-17}$

Changes in posture causing head and neck misalignment, lead to changes in the position of the cervical spine, hyoid bone, mandible and soft tissues of the pharynx, with consequent alteration of vocal resonance. ${ }^{2,18}$ The misalignment of the cervical spine also causes anteriorization of the styloid bone, resulting in an adaptive shortening of the stylohyoid muscle. This causes elevation of the larynx and alteration vocal tract shape, 19,20 with a change in resonance and pitch. An increase of the lumbar lordosis also causes an adaptive elevation of the head, causing an inflexible respiratory pattern resulting in a compression of the vocal tract. 9.21

From the above, it appears that any change in normal posture can have an influence on the mechanisms of vocal production.

The aim of this review is to summarize the literature regarding the use of posturography technology for evaluation of posture in vocal production or vocal pathology. 


\section{METHODS}

The authors searched MEDLINE (1949-2018). All studies were included if they dealt with the influence of posture on vocal production, using posturography.

\section{RESULTS}

The normal and ideal upright posture, ${ }^{4.5}$ can be defined as a vertical line drawn on the body, like a plumb line from head to toe, anterior to the spine. This imaginary line drawn in profile would represent a reference line passing through the mastoid/external ear, the most anterior point of the shoulder joint, a point slightly posterior to the hip joint, a point anterior to the centre of the knee joint and at the point of the ankle joint. It is the balance of muscular activity that maintains and realigns the body to this ideal position and produces stability. Any deviation from this alignment leads to incorrect posture.

In normal posture, the spine makes four natural curvatures: cervical lordosis, thoracic kyphosis, lumbar lordosis and sacred kyphosis. Increased thoracic kyphosis is the most common imbalance in spinal alignment, resulting in anterior shoulder rotation, forward head posture, and abnormal increase in all other spinal curvatures. ${ }^{5}$

Maintaining posture involves a series of dynamic mechanisms for maintaining balance when forces act in the body in various directions. ${ }^{4}$

When standing upright, it is normal for the body to sway back and forth, but if the movement continues out of control, the individual falls. Postural muscle activity that prevents loss of balance receives information through sensory receptors: visual, vestibular and proprioceptive. These receptors detect any imbalance stimulus and evoke a contrary muscular activity that will counter the oscillation, to keep postural control.

In recent years, the relationship between postural control and vocal function has been studied.8,22-30 (Table 1).

Between 1998 and 2010 a group from Marseille conducted a series of studies with the aim of evaluating postural changes during vocal effort. ${ }^{22-27}$

In the first one,22 the authors compared the postural features and segmental activity of forced voice between seventeen women without voice complaints and ten women with dysphonia (6 patients with nodules and four patients with polyps). They used an accelerometer to measure the head movement; a cine-analysis method to evaluate the angle between the chin, ear and the shoulder; and a rudimentary static postural platform (following the rules of the French Posturology Society) to measure the displacement of the centre of gravity. They demonstrated that in the individual without voice complaints, vocal effort results in segmental alterations of posture, with a backwards rotation of the head and synchronous advancement of the chin and translation of the head forward. In dysphonic patients, they observed broader and irregular movement and an increased angle between the chin, ear and the shoulder during phonation. They also demonstrated, using a static posturography platform, that those segmental postural alterations are accompanied by global postural changes, even in normal individuals. Dysphonic individuals demonstrate a greater displacement of the center of gravity forward, which results in postural instability, increasing muscular work to maintain the posture and balance of the individual. Segmental changes lead to global changes in balance because they interfere with the vestibular, visual and proprioceptive inputs; the sensory pathways that regulate postural control. The authors postulate that in dysphonic individuals, postural compensations (shoulder girdle, pelvic girdle and ankle joint) are limited by muscular tension, leading to overall skeletal rigidity. ${ }^{22}$

In 2000,23 the same authors used the same static posturography platform to measure the displacement of the centre of gravity in 3 individuals with the simultaneous evaluation of electromyographic activity of lower limbs muscles, to prove the muscle activation during the vocal effort. As expected they found a correlation between the increases in variance of the speed of displacement of the centre of gravity and the increase in the electrical signal from the postural muscles.

Giovanni et al, ${ }^{24}$ in 2006, used a more sophisticated static posturography platform (Médicapteurs, Toulouse) and an ELITE ${ }^{\circledR}$ system (digital hardware system for movement analysis) to analyse 19 subjects without voice disorders during vocal effort. They measured the root mean square of the velocity of variation of the centre of pressure (VCOP rms) in three different protocols: standing at rest versus holding a $3 \mathrm{~kg}$ weight in 15 subjects (protocol 1); standing while reading a text to a listener a 1.5 meters versus reading a 4 meters of distance in 17 subjects (protocol 2); reading in silence versus in a noise environment in 19 subjects (protocol 3). They confirm the postural changes found in the first study $^{22}$ and the increase in global muscle work during vocal effort. 
TABLE 1. Comparison of number of patients, methods used and valuable points in the principal clinical studies.

\begin{tabular}{|c|c|c|c|}
\hline STUDY & NUMBER OF PATIENTS & METHOD & VALUABLE POINTS/ LIMITATIONS \\
\hline Grini, ${ }^{22} 1998$ & $\begin{array}{l}10 \text { dysphonic patients ( } 6 \text { nod- } \\
\text { ules }+4 \text { polyps) } \\
17 \text { healthy subjects }\end{array}$ & $\begin{array}{l}\text { Accelerometer + Cine-anal- } \\
\text { ysis + Static posturography }\end{array}$ & $\begin{array}{l}\text { - Vocal effort results in segmental alteration of posture } \\
\text { - Speed of displacement of center of gravity was the } \\
\text { most useful discrimination factor }\end{array}$ \\
\hline Grini, ${ }^{23} 2000$ & 3 normal subjects & $\begin{array}{l}\text { Static posturography + } \\
\text { EMG lower limbs }\end{array}$ & $\begin{array}{l}\text { - Correlation between the increase in variance of the } \\
\text { speed of displacement of center of gravity and the in- } \\
\text { crease in the electrical signal from the postural muscles }\end{array}$ \\
\hline Giovanni, ${ }^{24} 2006$ & 19 normal subjects & $\begin{array}{l}\text { Static posturography }+ \\
\text { ELITE system }\end{array}$ & $\begin{array}{l}\text { - Confirm the postural changes, with increase in global } \\
\text { muscles work during vocal effort }\end{array}$ \\
\hline Giovanni, ${ }^{27} 2008$ & 60 normal subjects & $\begin{array}{l}\text { Static posturography + } \\
\text { EMG lower limbs }\end{array}$ & $\begin{array}{l}\text { - Increased vocal effort is associated with the velocity } \\
\text { of variation of the center of pressure and EMG signal } \\
\text { variation. } \\
\text { - VCOP is an indicator of postural muscle stiffening } \\
\text { during phonation }\end{array}$ \\
\hline Lagier, ${ }^{26} 2009$ & 20 normal subjects & $\begin{array}{l}\text { Static posturography + } \\
\text { EMG lower limbs + Acous- } \\
\text { tic system }\end{array}$ & $\begin{array}{l}\text { - Amplitude and duration of body movements increased } \\
\text { with vocal effort } \\
\text { - Only head movements for small efforts and major } \\
\text { head and trunk movements for bigger efforts }\end{array}$ \\
\hline Lagier, ${ }^{25} 2010$ & 20 normal subjects & $\begin{array}{l}\text { Static posturography + } \\
\text { EMG lower limbs + Acous- } \\
\text { tic system }\end{array}$ & $\begin{array}{l}\text { - Amplitude and duration of body movements increased } \\
\text { with vocal effort } \\
\text { - Only head movements for small efforts and major } \\
\text { head and trunk movements for bigger efforts } \\
\text { - Movement anticipates phonation } \\
\text { - Head movement may be involved in improving vocal } \\
\text { efficiency, and the forward trunk bending may empha- } \\
\text { size the effortful aspect of the communication }\end{array}$ \\
\hline Bruno, ${ }^{28} 2009$ & $\begin{array}{c}15 \text { dysphonic patients ( } 8 \\
\text { nodules }+7 \text { muscle tension } \\
\text { dysphonia) } \\
10 \text { healthy subjects }\end{array}$ & $\begin{array}{l}\text { Videolaryngostroboscopy } \\
+ \text { Vocal spectrography + } \\
\text { VHI + Computorized Static } \\
\text { posturography before and } \\
\text { after vocal rehabilitation }\end{array}$ & $\begin{array}{l}\text { - After vocal rehabilitation patients presented an im- } \\
\text { provement in proprioceptive component of posture }\end{array}$ \\
\hline Nacci, ${ }^{8} 2012$ & $\begin{array}{l}40 \text { hypokinetic dysfuncional } \\
\text { dysphonia }\end{array}$ & $\begin{array}{l}\text { Videolaryngostroboscopy } \\
\text { + Vocal spectrography + } \\
\text { VHI + GRBAS scale + Com- } \\
\text { putorized Static posturog- } \\
\text { raphy before and after } \\
\text { vocal rehabilitation }\end{array}$ & $\begin{array}{l}\text { - Greater proprioceptive awareness acquired through } \\
\text { speech therapy permits improvement in postural per- } \\
\text { formance in subjects with dysfunctional dysphonia }\end{array}$ \\
\hline Nacci, ${ }^{29} 2017$ & $\begin{array}{l}40 \text { organic dysphonia ( } 15 \text { vocal } \\
\text { fold polyps, } 11 \text { submucosal } \\
\text { cysts, } 10 \text { bilateral vocal fold } \\
\text { nodules, } 4 \text { Reinke's edema) }\end{array}$ & $\begin{array}{l}\text { Videolaryngostroboscopy } \\
\text { + Vocal acoustic evaluation } \\
\text { including spectrography + } \\
\text { VHI + GRBAS scale + Com- } \\
\text { putorized Static posturog- } \\
\text { raphy before and after } \\
\text { phonomicrosurgery }\end{array}$ & $\begin{array}{l}\text { - Absence of postural alterations in basal conditions in } \\
\text { polyps, cyst and Reinke's oedema subgroup } \\
\text { - } 8 \text { patients with nodules had basal postural alterations } \\
\text { with no improvement after phonomicrosurgery } \\
\text { - Heterogeneous group of study } \\
\text { - Statistical analysis performed in a restrict number of } \\
\text { patients within each individual subgroup }\end{array}$ \\
\hline $\begin{array}{l}\text { Lobryeau-Desnus, }{ }^{30} \\
2010\end{array}$ & $\begin{array}{l}58 \text { dysphonic patients }+19 \\
\text { healthy singers }\end{array}$ & $\begin{array}{l}\text { VHI + Computerized } \\
\text { dynamic posturography } \\
\text { before and after vocal } \\
\text { rehabilitation }\end{array}$ & $\begin{array}{l}\text { - Limitation on vocal assessment methods before and } \\
\text { after therapy } \\
\text { - Improvement in the vestibular component of balance } \\
\text { after treatment }\end{array}$ \\
\hline
\end{tabular}

In 2008, using a force static platform designed by the authors, in conjunction with a muscular study by electromyography, Giovanni et al27 tested 60 individuals without vocal pathology, to evaluate if the velocity of variation of the center of pressure would be a valid postural index in the vocal evaluation. The subjects were analysed in four different protocols: standing with eyes open versus eyes closed in 9 subjects (protocol 1); standing at rest versus holding a $3 \mathrm{~kg}$ weight in 15 subjects (protocol 2); standing while reading a text to a listener a $1.5 \mathrm{~m}$ versus reading a $4 \mathrm{~m}$ of distance in 17 subjects (protocol 3); reading in silence versus in a noise environment in 19 subjects (protocol 4). They concluded that the deviation of the centre of pressure has utility as an indicator of postural muscle stiffness during speech. ${ }^{27}$

Lagier et al, ${ }^{26}$ trying to assess how posture and vocal acoustics are modified when a subject needs to communicate, studied 20 healthy young women, in vocal effort. This time the authors used a numerical infrared system for movement analysis (SMART ${ }^{\circledR}$ ); an acoustic system to measure vocal intensity and duration of speech; and electroglottography. The subjects had to dictate numbers to an observer in 3 different conditions, representing progressive vocal effort: $4 \mathrm{~m}$ distance in a silent environment; 10 m distance in a silent 
environment; and $10 \mathrm{~m}$ distance in a loud environment (average of $90 \mathrm{~dB}$ ). The results showed that there is an increase in the amplitude and duration of body movements with increased vocal effort, with only head movements for small efforts and major head and trunk movements for bigger efforts. ${ }^{26}$

One year later, ${ }^{25}$ the same authors, used a similar population, in the same experimental conditions, to try to understand if body movement is a side effect of vocal effort or an integral part of communication effort behaviour. They confirmed there is an increase in the amplitude and duration of body movements with increased vocal effort and observed that the movement anticipates phonation. They postulate that the head movement may be involved in improving vocal efficiency, and the forward trunk bending may emphasize the effortful aspect of the communication.

Bruno et $a^{28}$ studied the postural strategy in 15 individuals with dysfunctional dysphonia and ten individuals with normal voice as a control group, before and after speech therapy.

All individuals underwent a videolaryngostroboscopy, a vocal spectrography analysis, Voice Handicap Index questionnaire (VHI), and evaluation in a normalized computerized static posturography platform (S. Ve. P. Amplaid), before and after a period of vocal training.

They concluded that after vocal rehabilitation with improved voice quality, patients presented an improvement in posture parameters in static posturography, indicative of an improvement in the proprioceptive component. This finding is in line with the discovery of neuromuscular receptors in the abdominal muscles, intercostal muscles, diaphragm, and intrinsic muscles of the larynx, suggesting a relationship with proprioceptive control. ${ }^{12}$ The abdominal and intercostal muscles are closely associated with posture and play a fundamental role in breathing and vocal production. Postural changes at the thoracic or abdominal level lead to proprioceptive reflexes affecting breathing and position of the vocal folds, which in turn affects vocal production. ${ }^{12}$

Nacci et $a^{8}$ studied 40 patients with hypokinetic dysfunctional dysphonia, with a static platform (S. Ve. P. Amplaid), before and after speech therapy and obtained similar results. They concluded that modification in posture secondary to exogenous stimulation can affect the voice, while alterations to the voice production mechanism can cause modifications in posture. They stated that posturography evaluation of patients before and after vocal treatment may represent a clinically useful variable in evaluating the efficacy of vocal therapy.

In 2017, the same authors ${ }^{29}$ using the same platform studied 40 patients with organic dysphonia (15 vocal fold polyps, 11 vocal fold submucosal cysts, 10 bilateral vocal fold nodules and 4 Reinke's oedema) before and after phonomicrosurgery. They did not find postural alterations in basal conditions in polyps, cyst and Reinke's edema subgroup. In 8 patients with bilateral vocal fold nodules they found basal postural alterations in the center of gravity but it didn't improve after phonomicrosurgery.

Although static posturography studies contributed to advances in the knowledge of the relationship between posture and voice, the state of the art in balance and postural assessment is dynamic computerized posturography platform evaluation. This technique allows a more complete and rigorous study of the posture since it allows evaluating the visual, vestibular and proprioceptive sensory inputs.

In 2010, Lobryeau-Desnus $C$ et $a^{30}$ used dynamic computerized posturography (SMART Equitest ${ }^{\circledR}$ ) for the first time in the evaluation of patients with vocal pathology.

The authors studied 58 individuals with dysphonia and 19 singers as a control group. Although the improvement of $\mathrm{VHI}$ after speech therapy, authors did not do a videolaryngostroboscopic evaluation nor an acoustic or a perceptual vocal evaluation, to characterize de vocal pathology and the improvement of vocal quality after speech therapy. Although this study has several limitations on vocal assessment method, posturographic findings showed that after speech therapy, patients demonstrated a significant improvement in the vestibular component of the balance. ${ }^{28}$

\section{CONCLUSION}

The relationship between postural control and vocal function has been studied and accepted in the literature. Body posture interferes with larynx position, respiratory function and vocal tract shape, influencing vocal production and performance, in normal and in dysphonic patients.

The use of evaluation and correction techniques of global postural dynamics in vocal patients is less well documented and one area in need of more scientific studies.

CONFLICTS OF INTEREST: The authors declare that they have no conflicts of interest. 
FINANCIAL SUPPORT: This work has not received any contribution, grant or scholarship.

CONFLITOS DE INTERESSE: Os autores declaram não ter qualquer conflito de interesse na realização do presente trabalho.

FONTES DE FINANCIAMENTO: Não houve qualquer fonte de financiamento na realização do presente trabalho.

\section{REFERENCES}

1. Rubin JS, Mathieson L, Blake E. Posture and voice. J Sing. 2004;60:270-5.

2. Heman-AckahYD. Physiology of voice production: considerations for the vocal performer. J Sing. 2005;62:173-6.

3. Behrman A. Common practices of voice therapists in the evaluation of patients. J Voice. 2005;19:454-69.

4. Schneider C, Dennehy CA, Saxon KG. Exercise physiology principles applied to vocal performance: the improvement of postural alignment. J Voice. 1997;11:332-7.

5. Arboleda BM, Frederick A. Considerations for maintenance of postural alignment for voice production. J Voice. 2008;22:909.

6. Feldenkrais M. Body and Mature Behavior. New York: International Universities Press; 1949.

7. Rubin JS, Blake E, Mathieson L. The effects of posture on Voice. In: Sataloff R, editor. Professional Voice: The Science and art of clinical care. $3^{\text {rd }}$ ed. San Diego: Plural Publishing; 2005. p.627-35.

8. Nacci A, Fattori B, Mancini V, Panicucci E, Mateucci J, Ursino $F$, et al. Posturographic analysis in patients with dysfunctional dysphonia before and after speech therapy/rehabilitation treatment. Acta Otorhinolaryngol Ital. 2012;32:115-21.

9. Iwarsson J. Effect of inhalatory abdominal wall movement on vertical laryngeal position during phonation. J Voice. 2001;15:384-94.

10. Hertegard S, Gauffin J, Sunderberg J. Open and covered singing as studied by means of fiberoptics, inverse filtering, and spectral analysis. J Voice. 1990;4:220-30.

11. Iwarsson J, Sunderberg J. Effect of lung volume on vertica larynx position during phonation. J Voice. 1998;12:159-65.

12. Gould WJ. Effect of respiratory and postural mechanisms upon action of the vocal cords. Folia Phoniat. 1971;23:211-24.

13. Staes FF, Jansen L, Vilette A, Coveliers Y, Daniels K, Decoster W. Physical therapy as a means to optimize posture and voice parameters in students' classical singers: a case report. J Voice. 2011;25:91-101.

14. Hodges PW, Sapsford R, Pengel LH. Postural and respiratory functions of the pelvic floor muscles. Neurourol Urodyn. 2007;26:362-71.

15. O'Sullivan PB, Grahamslaw KM, Kendell M, Lapenskie SC, Moller NE, Richards KV. The effect of different standing and sitting posture on trunk muscles activity in a pain-free population. Spine. 2002;27:1238-44.

16. Saunders SW, Rath D, Hodges PW. Postural and respiratory activation of the trunk muscles changes with mode and speed of locomotion. Gait Posture. 2004;20:280-90.

17. Urquhart DM, Hodges PW, Story $\mathrm{H}$. Postural activity of the abdominal muscles varies between regions of these muscles and between body positions. Gait Posture. 2005;22:295-301.
18. Chapman JL. Singing and teaching singing: A holistic an approach to classical voice. San Diego: Plural Publishing; 2006.

19. Anegawa E, Tsuyama H, Kusukawa J. Lateral cephalometric analysis of the pharyngeal airway space affected by head posture. Int J Oral Maxillofac Surg. 2008;37:805-9.

20. Muto T, Takeda S, Kanazawa M, Yamazaki A, Fujiwara Y, Mizoguchi I. The effect of head posture on the pharyngeal airway space. Int J Oral Maxillofac Surg. 2002;31:579-83.

21. Franco D, Martins F, Andrea M, Fragoso I, Carrão L, Teles J. Is the sagittal postural alignment different in normal and dysphonic adult speakers? J Voice. 2014;28:523.e I-8.

22. Grini MN, Ouaknine M, Giovanni A. Postural and segmental modifications of the forced voice. Rev Laryngol Otol Rhinol. 1998;119:253-7.

23. Grini MN, Ouaknine M, Giovanni A. Forcing the voice and variance of speed: correlation between the speed of displacement of the center of gravity and the work of the postural muscles. Rev Laryngol Otol Rhinol. 2000;121:319-23.

24. Giovanni A, Assaiante C, Galmiche A, Vaugoyeau M, Ouaknine M, Le Huche F. Vocal forcing and posture: experimental studies on normal subject. Rev Laryngol Otol Rhinol. 2006;127:28591.

25. Lagier A, Vaugoyeau M, Ghio A, Legou T, Assaiante C, Giovanni A. Coordination between posture and phonation in vocal effort behavior. Folia Phoniatr Logop. 2010;62:195-202.

26. Lagier A, Vaugoyeau M, Bouché C, Ghio A, Legou T, Assaiante C, et al. Postural study on healthy subjects during experimental vocal effort. Rev Laryngol Otol Rhinol. 2009;130:11-6.

27. Giovanni A, AkI L, Ouaknine M. Postural dynamics and vocal effort: preliminary experimental analysis. Folia Phoniatr Logop. 2008;60:80-5.

28. Bruno E, De Padova A, Napolitano B, Marroni P, Batelli R, Ottaviani F, et al. Voice disorders and posturography: variables to define the success of rehabilitative treatment. J Voice. 2009;23:71-5.

29. Nacci A, Romeu SO, Berrettini S, Matteucci J, Cavaliere MD, Mancini $\vee$ et al. Stabilometric findings in patients affected by organic dysphonia before and after phonomicrosurgery. Acta Otorhinolaryngol Ital. 2017;37:286-94.

30. Lobryeau-Desnus C, Girard P, Daguenant C, Constant O, Rallo M, Jamet S. Rehabilitation strategies of dysfunctional dysphonia in relation to posture. Rev Laryngol Otol Rhinol. 2010;131:69-72. 